\title{
Alveolar Type II Cells and Pulmonary Surfactant in COVID-19 Era
}

\author{
Andrea CALKOVSKA ${ }^{1}$, Maros KOLOMAZNIK ${ }^{2}$, Vladimir CALKOVSKY ${ }^{3}$ \\ ${ }^{1}$ Department of Physiology, Jessenius Faculty of Medicine in Martin, Comenius University in \\ Bratislava, Martin, Slovak Republic, ${ }^{2}$ Martin Biomedical Centre, Jessenius Faculty of Medicine in \\ Martin, Comenius University in Bratislava, Martin, Slovak Republic, ${ }^{3}$ Clinic of Otorhino- \\ laryngology and Head and Neck Surgery, Jessenius Faculty of Medicine in Martin, Comenius \\ University in Bratislava and Martin University Hospital, Martin, Slovak Republic
}

Received July 18, 2021

Accepted August 12, 2021

\section{Summary}

In this review, we discuss the role of pulmonary surfactant in the host defense against respiratory pathogens, including novel coronavirus SARS-CoV-2. In the lower respiratory system, the virus uses angiotensin-converting enzyme 2 (ACE2) receptor in conjunction with serine protease TMPRSS2, expressed by alveolar type II (ATII) cells as one of the SARS-CoV-2 target cells, to enter. ATII cells are the main source of surfactant. After their infection and the resulting damage, the consequences may be severe and may include injury to the alveolar-capillary barrier, lung edema, inflammation, ineffective gas exchange, impaired lung mechanics and reduced oxygenation, which resembles acute respiratory distress syndrome (ARDS) of other etiology. The aim of this review is to highlight the key role of ATII cells and reduced surfactant in the pathogenesis of the respiratory form of COVID-19 and to emphasize the rational basis for exogenous surfactant therapy in COVID-19 ARDS patients.

\section{Key words}

Pulmonary surfactant - Alveolar type II cell - SARS-CoV-2 • COVID-19 • ARDS

\section{Corresponding author}

V. Calkovsky, Clinic of Otorhinolaryngology and Head and Neck Surgery, Jessenius Faculty of Medicine, Comenius University, University Hospital Martin, Kollarova 2, 03601 Martin, Slovak Republic. E-mail: vladimir.calkovsky@uniba.sk

\section{Introduction}

Pulmonary surfactant is a unique lipoprotein complex that lines the inner surface of the alveoli and small airways (Johansson and Curstedt 1997). From the first breath of the newborn, surfactant plays a key role in the physiology of the respiratory system. It reduces the surface tension at the air-liquid interface and prevents alveolar collapse, stabilizes the alveolar-capillary barrier, prevents edema, and allows for effective gas exchange and oxygenation (Mirastschijski et al. 2020). In the most common pulmonary form of the disease caused by novel coronavirus, SARS-CoV-2 enters and causes injury to target cells including type II alveolar (ATII) cells that express angiotensin-converting enzyme 2 (ACE2) (Bezara et al. 2020). Disruption of surfactant metabolism has wide consequences arising from its multiple functions. During the COVID-19 pandemic, surfactant attracted attention especially because of the defensive and immunomodulatory properties of surfactant lipids and proteins (Han and Mallampalli 2015). Surfactant dysfunction or deficiency in COVID-19 has typical pathophysiological, morphological, and clinical manifestations (Ochs et al. 2021, Gattinoni et al. 2021). The treatment for respiratory failure in acute respiratory distress syndrome (ARDS) is based on the current understanding of the central role that ATII cells and surfactant play in SARS-COV-2 infection and is inspired by the success of the use of surfactant replacement therapy in neonatal RDS (Koumbourlis and Motoyama 2020). 


\section{Pulmonary surfactant and its role in the host immune system}

The respiratory system is a large interface between the body and the external environment. It is permanently exposed to toxins and pathogens and therefore requires effective local defense (Kolomaznik et al. 2017). Pulmonary surfactant is a complex substance that is synthesized and secreted by ATII cells. It contains about $90 \%$ lipids and $10 \%$ proteins, including the specific proteins SP-A, SP-B, SP-C, and SP-D (Johansson and Curstedt 1997). Surfactant covers the inner surface of the lungs and reduces surface tension at the alveolar surface to prevent collapse and facilitate gas exchange. It also prevents lung edema, relaxes the airway smooth muscle, and possesses multiple immune functions (Han and Mallampalli 2015). Surfactant, together with epithelial and endothelial cells, is part of the alveolarcapillary barrier. This barrier is susceptible to bacterial and viral infection that initiates a number of pathological events and finally leads to barrier breakdown (Gotts $e t$ al. 2014, Nova et al. 2019). Its dysfunction is followed by influx of neutrophils, protein leakage to alveolar space, edema, cell apoptosis and necrosis, and the inhibition of pulmonary surfactant, which are all typical signs of acute lung injury.

SP-A and SP-D are pulmonary collectins. They act as opsonins and bind to viruses to facilitate pathogen removal and regulate the function of inflammatory cells (Wright 2005, Watson et al. 2021). Disruption of this function leads to higher susceptibility to viral and bacterial infections. SP-A and SP-D prevent infection of epithelial cells through viral neutralization, agglutination, and enhanced phagocytosis (Hartshorn 2010). Pulmonary collectins also bind to the glycoproteins of viruses, including HIV, RSV, and SARS coronavirus, and to the hemagglutinin and neuraminidase of influenza $A$ virus to inhibit their activity (Han and Mallampalli 2015, Kishore et al. 2020). Recently, the role of the genetics of innate immune molecules, SP-A1 and SP-A2, and their differential impact on the local lung microenvironment and host defense was addressed as a background of diverse expression of COVID-19 (Tekos et al. 2020). A recombinant fragment of human SP-D (rfhSP-D), composed of homotrimeric neck and carbohydraterecognition domain, was shown to interact with S1 protein of SARS-CoV-2 and its receptor-binding domain in a dose-dependent manner. sfhSP-D acts as an entry inhibitor of SARS-CoV-2 infection by restricting the viral entry into HEK293T cells overexpressing angiotensin-converting enzyme 2 (ACE2) receptor. Treatment with $1.67 \mu \mathrm{M}$ rfhSP-D inhibited viral replication in clinical samples of SARS-CoV-2-positive cases by $\sim 5.5$-fold and was more efficient than remdesivir $(100 \mu \mathrm{M})$ in Vero cells. An approximately two-fold reduction in viral infectivity was also observed after treatment with $1.67 \mu \mathrm{M}$ rfhSP-D (Hsieh et al. 2021, Madan et al. 2021).

SP-A and SP-D in the circulatory system may serve as novel markers that can be used in the clinical course, prognosis, and follow-up of patients with COVID-19 (Kerget et al. 2020, Ghati et al. 2021), in addition to IL-6 or KL-6 (Krebs von den Lungen) produced by damaged or regenerating ATII cells (d'Alessandro et al. 2020).

SP-B and SP-C possess distinct immunomodulatory properties besides their stabilizing effect on surfactant film (Mulugeta and Beers 2006, Glasser et al. 2009) and also as a part of synthetic surfactant preparations (Mikolka et al. 2021). The antiinflammatory features were also demonstrated for protein-free lipid mixtures, DPPC (Gille et al. 2007), phosphatidylglycerol (Numata et al. 2010), and its analogs (Kandasamy et al. 2016) or some minor anionic surfactant phospholipids (Kuronuma et al. 2009, Voelker and Numata 2019). Surfactant lipids inhibited infection by the pandemic H1N1 influenza virus in several animal models (Numata et al. 2020).

Surfactant as a surface active agent, a "soap," may penetrate the virus coat, split it, and let the content be released into the environment. The new coronavirus may suppress the surfactant production in ATII cells to survive by using the ACE2 receptor in the infected lung tissue (Takano 2020). As a consequence of this hypothesis, pulmonary surfactant or its stimulants may be effective in the treatment and prophylaxis for COVID-19 (Takano 2020). Others also draw attention to the lipid pattern regulation in the respiratory system as a possible target of both treatment and prophylaxis against COVID-19 and other enveloped virus pneumonia (Mandato and Vajro 2021).

\section{Alveolar type II cells as a target for SARS- CoV-2}

The alveolar epithelium is made of alveolar type I (ATI) cells and ATII cells. ATII cells are small cuboid-shaped cells with a surface area of about $250 \mu \mathrm{m}^{2}$. 
They represent about $5-7 \%$ of the alveolar epithelial cells and have a typical morphology with lamellar bodies and microvilli at the apical surface (Mason 2006, Beers and Moodley 2017). The importance of alveolar type II cells has increased, as the lung is the major, although not exclusive, target organ in SARS-CoV-2 infection. ATII cells have multiple roles. They synthesize, secrete, and recycle pulmonary surfactant, which is an important factor for alveolar stability and host immunity (LopezRodriguez and Perez-Gil 2014). ATII cells produce other substances that affect the function of the immune system, such as cytokines, growth factors (Zissel et al. 2000), and endogenous antimicrobial peptides (Hiemstra et al. 2016, Nova et al. 2020). They serve as progenitors of ATI cells and, as such, contribute to alveolar epithelial repair and regeneration (Ruaro et al. 2021). Distinct subpopulations of ATII cells play the progenitor role in a different context. ATII cell subgroups behaving as stem cells during steady-state replacement are probably different from cells engaged in lung repair after injury. Moreover, some of the ATII cells may differentiate into ATII to ATI transition subpopulations (Chen and Liu 2020).

Damage or depletion of this population can lead to various pulmonary pathologies, including those related to the pulmonary form of COVID-19. ATII cells stabilize the alveolar-capillary barrier and are involved in lung fluid homeostasis and the maintenance of fluid-free alveoli by participating in sodium transport through sodium channels (Mason 2006). In acute lung injury, inflammatory cells infiltrate the alveoli and overproduce TNF- $\alpha$, which may affect epithelial sodium channels and cause pulmonary edema (Yamagata et al. 2009). Downregulation of alveolar $\mathrm{Na} / \mathrm{K}$-ATPase is also associated with pulmonary edema, as was shown in experimental models of lung injury as well as in clinical settings (Sznajder et al. 2002).

Angiotensin-converting enzyme (ACE2) protein is found in some airway cells and is highest within regions of the sinonasal cavity and pulmonary alveoli, which are the sites of viral transmission (Bezara et al. 2020). One of the highest expressions of both ACE2 and transmembrane protease serine 2 (TMPRSS2), a cofactor for SARS-CoV-2 entry, is in ATII cells (Ziegler et al. 2020, Carcaterra and Caruso 2021). In the lung parenchyma, ACE2 was found on the apical surface of a small subset of ATII cells and colocalized with TMPRSS2. About $83 \%$ of ACE2-expressing cells are ATII cells and $5 \%$ are ATI cells (Lukassen et al. 2020). ACE2-expressing ATII cells had high levels of multiple viral response-related genes, supporting the role of these cells in viral infection and control (Ziegler et al. 2020). Over $34 \%$ of ATII cells express TMPRSS2, $1.4 \%$ express $A C E 2$, and $0.8 \%$ co-express TMPRSS2 and $A C E 2$. This is in accordance with the report of Zou et al. (2020) on the average proportion of ACE2-positive ATII cells of about $1 \%$.

Other receptors expressed at ATII cells may also be involved in the development of COVID-19. Recently, it has been proposed that the spike protein of SARSCoV-2 has a strong interaction with TLR4, an innate immune receptor on the cell surface that recognizes pathogen-associated molecular patterns including viral proteins (Aboudounya and Heads 2021). In physiological conditions, two minor anionic phospholipids present in the pulmonary surfactant, palmitoyl-oleoylphosphatidylglycerol (POPG) and phosphatidylinositol (PI), block TLR2 and TLR4 in the lungs (Kuronuma et al. 2009, Voelker and Numata 2019). Therefore, infection of ATII cells with SARS-CoV-2 and the following lack of surfactant production may expose TLR4 on alveolar cells for the virus and promote inflammation and lung injury (Aboudounya and Heads 2021).

\section{Regulation of ACE2 expression on ATII cells}

COVID-19 tends to progress faster in elderly people (Vašků 2020). Interestingly, age, sex, and comorbidities do not increase ACE2 protein expression in the human respiratory tract (Bezara et al. 2020). While the expression of ACE2 and TMPRSS2 genes in the ATII cells in elderly and young patients are comparable, 263 different genes are downregulated in cells from the elderly, with superoxide dismutase 3 (SOD3), an important antioxidant enzyme, being most downregulated (Abouhashem et al. 2020). In patients on mechanical ventilation in comparison to non-ventilated individuals, ACE2 was strongly upregulated with age, which was associated with prominent expression in ATII cells. These findings provide a potential mechanism for a more severe course of COVID-19 in the elderly (Paces et al. 2020, Baker et al. 2021).

ACE2 receptors are activated by interferons, which enhances infection (Ziegler et al. 2020). It is proposed that the development of a such "hyperactive" immune response plays a role in the evolution of the disease. The presence of pan JAK/STAT components in ATII cells suggests that ACE2 is also activated by other cytokines (Hennighausen and Lee 2020). ACE2 has 
different expression levels in airways under distinct chronic inflammatory airway diseases, such as chronic obstructive pulmonary disease (COPD) and allergic asthma, which may affect the management of primary airway diseases in patients with COVID-19 (Yao et al. 2020). The expression of ACE2 in ATII cells is modulated by pollutants or cigarette smoke (Liu et al. 2021). Elevated oxygen levels did not affect the expression of ACE2 in cell culture but did increase the gene and protein expression of TMPRSS11D. Thus, oxygen supplementation can be a potential risk factor for COVID-19 (Myti et al. 2020).

\section{The models to study ATII cells and COVID-19}

Representative models to study virus vs. host interactions in the lungs in detail are not available. These models should be based on human cells relevant to the disease in order to study the behavior of SARS-CoV-2 and possible pharmacological interventions. In general, SARS-CoV-2 infection of human lung epithelia can be modelled by two basic methods: using stem cell technology and organoids. Human 2D and 3D cultures of differentiated cells and organoids allow for modelling of the structure and physiology of different tissues and organs (Trevisan et al. 2021). These in vitro cell systems are generated from induced pluripotent stem cells (iPSCs), primary cells, cell lines, and ex vivo tissue biopsies (Leibel et al. 2020, Han et al. 2021, Lamers et al. 2021, Leibel et al. 2021). ATII cells must retain their typical features, including the ability to self-renew, produce surfactants, and differentiate into ATI cells (Katsura et al. 2020). In preclinical studies, A549 cells are often used as a model for ATII cells. They do not seem convenient for this purpose because they come from human lung cancer-derived cell lines and lack the expression of important lung epithelial genes including several genes coding surfactant proteins. On the other hand, primary alveolar type II cells express SFTPA1, SFTPA2, SFTPC, and SFTPD as well as ACE2 and TMPRSS2, two genes encoding host cell proteins essential for SARS-CoV-2 cell entry (Abo et al. 2020).

\section{Morphological changes of alveolar type II cells}

The visualization of the ATII cells changed by SARS-CoV-2 infection helps to uncover the pathophysiology of respiratory failure. The majority of lung specimens are investigated post mortem and diffuse alveolar damage (DAD) in COVID-19 patients is the most relevant histologic pattern. The findings are usually equivalent to the pattern of alveolar epithelial injury of other etiology (Ochs et al. 2021). In lung sections from COVID-19 patients, the predominant feature was DAD with fibrosis in the final stage of illness (Santana et al. 2021); some patients showed focal pulmonary microthrombi (Bradley et al. 2020). In other autopsy and microscopy studies of deceased COVID-19 patients, the most important aspect was the focal cytopathic changes of ATII cells. Enlargement of ATII cells was accompanied by rich cytoplasm and enlarged irregular nucleus with a single-centered prominent nucleolus and inclusions situated at the periphery of the nucleus. In some areas, ATII cells tended to form clusters marked as multinucleated giant cell-like alveolar epithelial cell aggregates (Oprinca and Muja 2021). In general, all findings support cytokine storm and severe fibrosis in the lungs of COVID-19 patients (Chen et al. 2021).

The post mortem findings may differ from those of the earlier stages of the disease as shown by ante mortem investigation. Morphologically distinct features in early stages of COVID-19 pneumonia, with epithelial and endothelial cell abnormalities different from either classical interstitial lung diseases or diffuse alveolar damage, were shown by transbronchial lung cryobiopsy in twelve COVID-19 patients with moderate COVID-19 pneumonia. Within 20 days of symptom onset, this investigation revealed spots of patchy acute lung injury with ATII cell hyperplasia, with no evidence of hyaline membranes. Over $50 \%$ of ATII cells had strong nuclear expression of phosphorylated STAT3 proteins, involved in cytokine signaling (Doglioni et al. 2021). ATII cell hyperplasia was a prominent event in the majority of cases and may be considered an essential part of the epithelialization process in wound healing (Ruaro et al. 2021).

Using transmission electron microscopy, Ochs et al. (2021) suggested a sequence of events leading to the reduction of alveolar volume and alveolar gas exchange area. It begins with alveolar epithelial cell damage followed by surfactant dysfunction, alveolar instability, and microatelectasis. The process of collapse induration is further based on basal lamina denudation, collapse and sealing of the alveoli by proliferating alveolar epithelial cells, and the forming of thickened septa. This provides clear evidence of surfactant dysfunction and alveolar instability in fibrosis initiation, as well as evidence of early surfactant dysfunction as an important event in the pathophysiology of COVID-19. 
These, together with other data (e.g. Busani et al. 2020, Koumbourlis and Motoyama 2020) suggest that exogenous surfactant therapy may restore the surfactant system and prevent lung fibrosis in COVID-19 patients.

\section{Surfactant and ATII cells in SARS-CoV-2 infection: Implications for the pathophysiology of ARDS}

The lung injury in COVID-19 usually begins after an asymptomatic phase when the infection is not combatted by nasal mucosa (Pedan et al. 2020) and continues as a mildly symptomatic phase after involvement of the epithelium of the larger airways (Mason 2020). Consequently, SARS-CoV-2 infection of the ACE2-receptor bearing cells in the peripheral lungs induces a local immune response and may lead to severe lung damage (Paces et al. 2020), resulting in acute respiratory distress syndrome (ARDS). In general, the pathophysiology of ARDS is very complex (Otáhal et al. 2016, Mokrá 2020). New coronavirus-induced ARDS has several specific features. It affects mainly lungs, with minor damage to other organs. Its main characteristic is the dissociation between the severity of the hypoxemia and the maintenance of relatively good respiratory mechanics (Gattinoni et al. 2020). Sudden opening of a previously undetected probe-patent foramen ovale could explain this finding. Opening of such an intracardiac shunt would not worsen lung mechanical properties. The evidence of hypercoagulability and pulmonary embolisms at autopsy support this hypothesis, as they would contribute to increased pressure in the pulmonary arterial bed and the right heart, potentially leading to opening of a short circuit (Fisher 2020).

The lack of surfactant leads to increased surface tension, alveolar flooding, and atelectasis, resulting in ineffective gas exchange and respiratory failure (Mason 2020). The clinical manifestation may be relatively mild in some COVID-19 patients and the clinical symptomatology is inconsistent with the degree of laboratory and imaging findings ( $\mathrm{Li}$ and $\mathrm{Ma} 2020$ ). The timing of onset of COVID-19-related ARDS is about 8-12 days in contrast to ARDS Berlin criteria, which give 7 days as the onset limit (ARDS Definition Task Force 2012).

The main cause of COVID-19-related ARDS is injury to ATII cells resulting in altered surfactant production and lung fluid homeostasis (Morris et al. 2020). Viral infection of ATII cells activates the aberrant protein pathways followed by abnormal cross-talk between infected ATII cells and noninfected endothelial cells and induces the relaxation and dilation of pulmonary vessels. Finally, alveolar epithelial and endothelial cells die by pyroptosis and necroptosis (Morris et al. 2020). Activation of alveolar macrophages in close proximity to ATII cells contributes to overactivation of the inflammatory immune response, which can lead to a cytokine storm and subsequent immune exhaustion (Morris et al. 2020, Paces et al. 2020, Chen et al. 2021, Chilosi et al. 2021).

Viral proteins can target both transcription and epigenetic factors, which, in turn, modulate important members of the surfactant metabolism process, including SFTPB, SFTPC, and SFTPD genes (Islam and Khan 2020). Surfactant metabolism is modulated not only by viral proteins, but also through irregular host responses. Unaffected metabolism in ATII cells is crucial for surfactant synthesis. Its disruption could contribute to the pathogenesis of virus-induced ARDS, as it is associated with reduced levels of liponucleotides, essential precursors to de novo phospholipid synthesis in ATII cells. Altered surfactant metabolism may be reversed by diet, able to influence the lipidome of ATII cells (Rosas et al. 2021).

As mentioned above, the primary histological manifestation of severe lung disease in COVID-19 patients is diffuse alveolar damage with no distinctive morphological features with which to confidently differentiate COVID-19-related DAD from DAD due to other causes (Konopka et al. 2020). DAD includes an acute phase with alveolar epithelial injury, surfactant changes, and edema formation. Capillary congestion, platelet adhesion, fibrin thrombi, and rupture of the capillary walls complete the image. Because of the increased permeability of the alveolar-capillary barrier followed by transudation of plasma proteins, formation of hyaline membranes, and an inflammatory exudate, characteristic of ARDS, it is also called the exudative phase (Mason 2020). The late organizing phase with cuboidal metaplasia of ATII cells and thickening of interalveolar septa, ultimately resulting in either restoration or fibrosis, is also called proliferative (Ochs et al. 2021, Santana et al. 2021). It is clearly evidenced that surfactant alterations resulting from an initial alveolar epithelial injury lead to alveolar instability and collapse, followed by the unfolding and denudation of alveolar epithelial basal laminae and re-epithelialization (Ochs et al. 2021, Santana et al. 2021). Structural changes of the lungs and 
surfactant dysfunction affecting tissue mechanical behavior are similar to changes seen in another lung injury. Extensive alveolar microangiopathy further contributes to mechanical changes in the tissue (Dimbath et al. 2021).

In COVID-19 related ARDS, ATII cells infected by the virus may lose their ability for normal repair and contribute to the fibroproliferative reaction. This happens through the secretion of growth factors and proinflammatory molecules, which can finally result in lung fibrosis as a background for interstitial lung diseases (Mason 2020, Ruaro et al. 2021).

\section{Exogenous surfactant treatment in COVID-19 patients}

To date, no treatment has emerged as being significantly effective in patients with respiratory failure due to SARS-CoV-2 infection. Surfactant replacement therapy has been a routine part of the management of neonatal respiratory distress syndrome (RDS) over several decades. It improves the oxygenation and survival of babies with primary surfactant deficiency of prematurity (Herting et al. 2020). This treatment has also been tested for acute respiratory distress syndrome (ARDS). Even if some patients have benefitted from surfactant administration, several studies had to be terminated without convincing success, possibly due to the complexity of this syndrome (Schousboe et al. 2020, Veldhuizen et al. 2021). The pathomechanisms of COVID-19-induced ARDS are based on damage to ATII cells. The course of ARDS in COVID-19 patients is atypical and shows a discrepancy between severe hypoxemia and the relatively well-preserved mechanical behavior of the lungs, which makes it more similar to neonatal RDS (Koumbourlis and Motoyama 2020).

It is essential to understand the central role of pulmonary surfactant deficiency in SARS-CoV-2induced ARDS. It is justified to consider exogenous surfactant therapy as a rational and well-founded treatment in COVID-19 ARDS patients for the following reasons.

Administration of exogenous surfactant increases the surfactant pool in the lungs, which is reduced due to the damage of ATII cells and/or by the development of inflammation. It also restores alveolarcapillary barrier and, thus, reduces edema (Mirastschijski et al. 2020). Exogenous surfactant reduces inflammation by multiple mechanisms. Exposure of TLR4 in the lungs due to reduced pulmonary surfactant makes the receptors available for the SARS-CoV-2 to bind to and activate TLR4 to increase ACE2 expression, facilitating entry and causing hyperinflammation (Aboudounya and Heads 2021). By blocking TLR4, surfactant hinders this receptor-pathogen interaction (Kuronuma et al. 2009, Abate et al. 2010). Some surfactant phospholipid species may inhibit the initiating step of the pro-inflammatory signaling pathways and also inhibit inflammatory sequelae associated with virus infections (Voelker and Numata 2019). Surfactant may restore immune homeostasis, as it is a strong defender against the virus itself (Takano 2020). Surfactant lipids directly disrupt the virus particles binding to host cell plasma membrane receptors, required for viral uptake (Bollag and Gonzales 2020).

Reduction of surface tension in the alveoli and small airways after surfactant administration improves the gas exchange and mechanical behavior of the lungs, which is followed by an increase in oxygenation. Finally, the patient may benefit from early administration of pulmonary surfactant by the shortening of the duration of mechanical ventilation and enhanced weaning (Mirastschijski et al. 2020, Cattel et al. 2021). To achieve a synergistic effect, exogenous surfactant can be combined with anti-inflammatory, anti-oxidant, anti-viral, and anti-bacterial agents such as, e.g. ambroxol, which, in addition, has a direct impact on the production and secretion of the surfactant from the ATII cells (Kumar 2020).

Taken together, these data lead to a rational approach in the treatment of the disease by the administration of exogenous surfactant. Such treatment has the potential to contribute efficiently to the repair of damaged alveoli and to prevent the severe respiratory failure associated with SARS-CoV-2 infection. The success of such a treatment was documented by several case studies and encouraged the medical community to perform large international clinical phase 2 studies which are under way.

Exogenous surfactant therapy is also effective in very severe courses of COVID-19. A 48-year-old male non-smoker with COVID-19-related ARDS did not improve on ECMO for 5 days. On day 11 of hospitalization, he was administered five vials of $6 \mathrm{ml}$ surfactant (calfactant; $35 \mathrm{mg} / \mathrm{ml}$ phospholipid suspension, $20 \mathrm{mg}$ phospholipids/kg of body weight). Surfactant was administered via a tracheobronchial suction catheter passed through the endotracheal tube with the distal 
suction tip positioned above the carina, and then dispersed directly into the lungs during positioning of the patient. Based on improved oxygenation, the patient was weaned from ECMO after $36 \mathrm{~h}$, extubated the following day, and discharged 8 days later (Heching et al. 2021). The benefits of this treatment have also been shown by the retrospective analysis of data from seven COVID-19 ARDS patients receiving off-label exogenous surfactant poractant alfa at a dose of $720 \mathrm{mg}$ in $150 \mathrm{ml}$ physiological solution, divided into five $30 \mathrm{ml}$ aliquots. Surfactant was delivered via a bronchoscope into secondgeneration bronchi. The main finding was a trend toward the reduction of 28-days mortality within the surfactant group. Surfactant delivery through bronchoscopy has been suggested as being feasible, well-tolerated, and safe for COVID-19 ARDS patients and health care providers during the pandemic (Piva et al. 2021). Using computational fluid dynamics to simulate exogenous surfactant instillation with 3D human airway models and observing how it moves in the liquid layer covering the airway wall and reaches alveolar regions, it was concluded that selective wedge instillation under bronchoscopic observation should be tried for COVID-19 pneumonia before the onset of ARDS, which may also be useful for preventing secondary lung fibrosis (Kitaoka et al. 2021).

A single-center study in adult COVID-19 patients with moderate to severe ARDS requiring auxiliary respiratory devices is on the way. The exogenous surfactant beractant, bovine lung extract, is given in a standard-dose $4 \mathrm{ml}$ suspension containing $100 \mathrm{mg}$ phospholipids for an adult person with about $70 \mathrm{~kg}$ of body weight (b.w.). The first dose of surfactant is given intratracheally on the day of intubation and the second dose $6 \mathrm{~h}$ later. The main outcomes are 30 days mortality, mortality during stay in the intensive care unit (ICU) up to 30 days, an ICU stay of up to 30 days, and time under mechanical ventilation up to 30 days (Dabbagh et al. 2020).

At https://clinicaltrials.gov, seven studies using exogenous surfactant administration in adult patients with COVID-19 ARDS and designed mostly as clinical phase 2 studies are registered. Two studies use modified porcine surfactant poractant alfa. One study called "Curosurf ${ }^{\circledR}$ in Adult Acute Respiratory Distress Syndrome Due to COVID-19 (Caards-1)" is carried out in France. The patients receive either the bronchial fibroscopy alone (to aspirate the secretions) or a bronchial fibroscopy with administration of modified porcine surfactant poractant alfa at a dose of $3 \mathrm{ml} / \mathrm{kg}$ b.w. diluted to $16 \mathrm{mg} / \mathrm{ml}$ and distributed into each of the 5 lobar bronchi (https:/clinicaltrials.gov/ct2/show/NCT04384731). Another study using the same exogenous preparation is called "Poractant Alfa - Curosurf and SARS-COV-19 ARDS (COVID-19)" is being performed in the UK with 85 participants. The efficacy and safety of poractant alfa will be evaluated in terms of ventilatory-free days during the 21 days after randomization, in adult patients with ARDS due to SARS-CoV-2 infection. Patients receive three administrations with a 24-hour dosing interval; endo-tracheal administration 1, 2, and 3 will consist of poractant alfa bolus: $30 \mathrm{mg} / \mathrm{kg}$ b.w. $(0.375 \mathrm{ml} / \mathrm{kg} \mathrm{b.w.)}$ (https:/clinicaltrials.gov/ct2/show/NCT04502433). In "A Clinical Trial of Nebulized Surfactant for the Treatment of Moderate to Severe COVID-19 (COVSurf)", patients will be administered surfactant via the COVSurf Drug Delivery System or will receive regular Standard of Care treatment. This study evaluates the feasibility, safety and efficacy of nebulized surfactant in adult COVID-19 patients requiring mechanical ventilation for respiratory failure; the study is intended as a dose-escalating randomized open-label clinical trial of COVID-19 patients (Dushianthan et al. 2020, https://clinicaltrials.gov/ct2/show/NCT04362059). In "London's Exogenous Surfactant Study for COVID19 (LESSCOVID)," patients with COVID-19-induced respiratory failure will be randomly assigned to receive either standard treatment or standard treatment plus bovine lipid extract surfactant (BLES). BLES is administered in doses of $50 \mathrm{mg} / \mathrm{kg}$ b.w. at a concentration of $27 \mathrm{mg} / \mathrm{ml}$. The material will be instilled as soon as possible via the suction catheter through the endotracheal tube. The procedure will be repeated at 24 and $48 \mathrm{~h}$ during intubation, so the patient will receive up to 3 doses (https://clinicaltrials.gov/ct2/show/NCT04375735). The study "Surfactant-BL in Adult Acute Respiratory Distress Syndrome Due to COVID-19," performed in Russia, includes 4 different cohorts of patients who inhaled surfactant emulsion Surfactant-BL (Biosurf LLC, Russia) at $150 \mathrm{mg}$ every $12 \mathrm{~h}$ on the first, second, third, fourth, and fifth days of the treatment period, inclusive. Primary outcome measure is the mean duration of oxygen therapy (days) in the treatment group and in the control group (https:/clinicaltrials.gov/ct2/show/NCT04568018). Clinical trial "Exogenous Surfactant Through Nebulizer Mask on Clinical Outcomes in COVID-19 Patients (CovidSurf)" is aimed to evaluate the effect of exogenous nebulized surfactant in the pre-intubation stages of the 
disease. Nebulized surfactant would be administered by face mask, which has a nebulizer. The type of surfactant preparation is not listed (https://clinicaltrials.gov/ct2/show/NCT04847375). The patients in "The Safety and Preliminary Tolerability of Lyophilized Lucinactant in Adults With Coronavirus Disease 2019 (COVID-19)" study receive synthetic surfactant lucinactant (KL4-surfactant) as a liquid at a dose of $80 \mathrm{mg}$ total phospholipids $/ \mathrm{kg}$ b.w. Primary outcome measures are the safety and feasibility of lucinactant therapy in treating COVID-19 and oxygen index through $12 \mathrm{~h}$ post initiation of dosing (https://clinicaltrials.gov/ct2/show/NCT04389671).

\section{Conclusions}

SARS-Cov-2 enters via the ACE2 receptors of the ATII cells, producers of lung surfactant. Surfactant lipids and specific proteins protect the respiratory system against pathogens, including the novel coronavirus. Injury to the ATII cells considerably reduces the surfactant alveolar pool and leads to various respiratory symptomatology, including ARDS. Thus, the clinical manifestations of the pulmonary form of COVID-19 is a direct consequence of the involvement of ATII cells and surfactant deficiency. Clinical data provide rationale for using exogenous surfactant as a valid supportive treatment in COVID-19 patients. The potential of surfactant as being anti-inflammatory and lung-protective therapy is influenced by several variables, including the way of delivery, timing, dosing, and surfactant preparation as well as mechanical ventilation. Pulmonary surfactant as a target for SARS-CoV-2 infection can become a means for suppressing the consequences of this infection.

\section{Conflict of Interest}

There is no conflict of interest.

\section{Acknowledgements}

The work was supported by projects VEGA 1/0055/19, VEGA 1/0004/21 and APVV-17-0250.

\section{References}

ABATE W, ALGHAITHY AA, PARTON J, JONES KP, JACKSON SK: Surfactant lipids regulate LPS-induced interleukin-8 production in A549 lung epithelial cells by inhibiting translocation of TLR4 into lipid raft domains. J Lipid Res 51: 334-344, 2010. https://doi.org/10.1194/jlr.M000513

ABO KM, MA L, MATTE T, HUANG J, ALYSANDRATOS KD, WERDER RB, MITHAL A, BEERMANN ML, LINDSTROM-VAUTRIN J, MOSTOSLAVSKY G, IKONOMOU L, KOTTON DN, HAWKINS F, WILSON A, VILLACORTA-MARTIN C: Human iPSC-derived alveolar and airway epithelial cells can be cultured at air-liquid interface and express SARS-CoV-2 host factors. BioRxiv (Preprint) 2020: 132639, 2020. https://doi.org/10.1101/2020.06.03.132639

ABOUDOUNYA MM, HEADS RJ: COVID-19 and toll-like receptor 4 (TLR4): SARS-CoV-2 may bind and activate TLR4 to increase ACE2 expression, facilitating entry and causing hyperinflammation. Mediators Inflamm 2021: 8874339, 2021. https://doi.org/10.1155/2021/8874339

ABOUHASHEM AS, SINGH K, AZZAZY HME, SEN CK: Is low alveolar type II cell SOD3 in the lungs of elderly linked to the observed severity of COVID-19? Antioxid Redox Signal 33: 59-65, 2020. https://doi.org/10.1089/ars.2020.8111

ARDS DEFINITION TASK FORCE, RANIERI VM, RUBENFELD GD, THOMPSON BT, FERGUSON ND, CALDWELL E, FAN E, CAMPOROTA L, SLUTSKY AS: Acute respiratory distress syndrome: The Berlin definition. JAMA 307: 2526-2533, 2012. https://doi.org/10.1001/jama.2012.5669

BAKER SA, KWOK S, BERRY GJ, MONTINE TJ: Angiotensin-converting enzyme 2 (ACE2) expression increases with age in patients requiring mechanical ventilation. PLoS One 16: e0247060, 2021. https://doi.org/10.1371/journal.pone. 0247060

BEERS MF, MOODLEY Y: When is an alveolar type 2 cell an alveolar type 2 cell? A conundrum for lung stem cell biology and regenerative medicine. Am J Respir Cell Mol Biol 57: 18-27, 2017. https://doi.org/10.1165/rcmb.2016-0426PS

BEZARA MEO, THURMAN A, PEZZULO AA, LEIDINGER MR, KLESNEY-TAIT JA, KARP PH, PING TAN P, WOHLFORD-LENANE C, MCCRAY PB JR, MEYERHOLZ DK: Heterogeneous expression of the SARS-Coronavirus-2 receptor ACE2 in the human respiratory tract. BioRxiv (Preprint) 2020: 056127, 2020. https://doi.org/10.1101/2020.04.22.056127 
BOLLAG WB, GONZALES J: Phosphatidylglycerol and surfactant: A potential treatment for COVID-19? Med Hypotheses 144: 110277, 2020. https://doi.org/10.1016/j.mehy.2020.110277

BRADLEY BT, MAIOLI H, JOHNSTON R, CHAUDHRY I, FINK SL, XU H, NAJAFIAN B, DEUTSCH G, LACY JM, WILLIAMS T, YARID N, MARSHALL DA: Histopathology and ultrastructural findings of fatal COVID19 infections in Washington State: a case series. Lancet 396: 320-332, 2020. https://doi.org/10.1016/S0140$\underline{6736(20) 31305-2}$

BUSANI S, DALL'ARA L, TONELLI R: Surfactant replacement might help recovery of low-compliance lung in severe COVID-19 pneumonia. Ther Adv Respir Dis 14: 1-6, 2020. https://doi.org/10.1177/1753466620951043

CARCATERRA M, CARUSO C: Alveolar epithelial cell type II as main target of SARS-CoV-2 virus and COVID-19 development via NF-Kb pathway deregulation: A physio-pathological theory. Med Hypotheses 146: 110412, 2021. https://doi.org/10.1016/j.mehy.2020.110412

CATTEL F, GIORDANO S, BERTIOND C, LUPIA T, CORCIONE S, SCALDAFERRI M, ANGELONE L, DE ROSA FG: Use of exogenous pulmonary surfactant in acute respiratory distress syndrome (ARDS): Role in SARS-CoV-2related lung injury. Respir Physiol Neurobiol 288: 103645, 2021 https://doi.org/10.1016/j.resp.2021.103645

CHEN R, LAN Z, YE J, PANG L, LIU Y, WU W, QIN X, GUO Y, ZHANG P: Cytokine storm: The primary determinant for the pathophysiological evolution of COVID-19 deterioration. Front Immunol 12: 589095, 2021. https://doi.org/10.3389/fimmu.2021.589095

CHEN Q, LIU Y: Heterogeneous groups of alveolar type II cells in lung homeostasis and repair. Am J Physiol Cell Physiol 319: C991-C996, 2020. https://doi.org/10.1152/ajpcell.00341.2020

CHEN XJ, LI K, XU L, YU YJ, WU B, HE YL, ZHAO WE, LI D, LUAN CX, HU L, WANG J, DING JJ, YU YF, LI JX, TAN ZM, LIU XF, WEI D, ZHANG ZH, GUO XJ, SU C, HU ZB, GUO YS, CHEN JY, CHEN F: Novel insight from the first lung transplant of a COVID-19 patient. Eur J Clin Invest 51: e13443, 2021. https://doi.org/10.1111/eci.13443

CHILOSI M, POLETTI V, RAVAGLIA C, ROSSI G, DUBINI A, PICIUCCHI S, PEDICA F, BRONTE V, PIZZOLO G, MARTIGNONI G, DOGLIONI C: The pathogenic role of epithelial and endothelial cells in early-phase COVID-19 pneumonia: victims and partners in crime. Mod Pathol 34: 1444-1455, 2021. https://doi.org/10.1038/s41379-021$\underline{00808-8}$

DABBAGH A, RAJAEI S, GHAHREMANI M, FATHI M, MASSOUDI N, TAVANA S, FANI K, NOORAEE N, MALEKPOUR ALAMDARI N, BESHARAT S, NAJAFI ABRANDABADI A, PIRSALEHI A, KHABIRI KHATIRI MA: The effect of surfactant on clinical outcome of patients with COVID-19 under mechanical ventilation: A structured summary of a study protocol for a randomised controlled trial. Trials 21: 919, 2020. https://doi.org/10.1186/s13063-020-04815-Z

D'ALESSANDRO M, CAMELI P, REFINI RM, BERGANTINI L, ALONZI V, LANZARONE N, BENNETT D, RANA GD, MONTAGNANI F, SCOLLETTA S, FRANCHI F, FREDIANI B, VALENTE S, MAZZEI MA, BONELLA F, BARGAGLI E: Serum KL-6 concentrations as a novel biomarker of severe COVID-19. J Med Virol 92: 2216-2220, 2020. https://doi.org/10.1002/jmv.26087

DIMBATH E, MADDIPATI V, STAHL J, SEWELL K, DOMIRE Z, GEORGE S, VAHDATI A: Implications of microscale lung damage for COVID-19 pulmonary ventilation dynamics: A narrative review. Life Sci 274: 119341, 2021. https://doi.org/10.1016/j.lfs.2021.119341

DOGLIONI C, RAVAGLIA C, CHILOSI M, ROSSI G, DUBINI A, PEDICA F, PICIUCCHI S, VIZZUSO A, STELLA F, MAITAN S, AGNOLETTI V, PUGLISI S, POLETTI G, SAMBRI V, PIZZOLO G, BRONTE V, WELLS AU, POLETTI V: Covid-19 interstitial pneumonia: Histological and immunohistochemical features on cryobiopsies. Respiration 100: 488-498, 2021. https://doi.org/10.1159/000514822

DUSHIANTHAN A, CLARK H, MADSEN J, MOGG R, MATTHEWS L, BERRY L, DE LA SERNA JB, BATCHELOR J, BREALEY D, HUSSELL T, PORTER J, DJUKANOVIC R, FEELISCH M, POSTLE A, GROCOTT MPW: Nebulised surfactant for the treatment of severe COVID-19 in adults (COV-Surf): A structured summary of a study protocol for a randomized controlled trial. Trials 21: 1014, 2020. https://doi.org/10.1186/s13063-020-04944-5

FISHER HK: Hypoxemia in COVID-19 patients: An hypothesis. Med Hypotheses 143: 110022, 2020. https://doi.org/10.1016/j.mehy.2020.110022 
GATTINONI L, CHIUMELLO D, ROSSI S: COVID-19 pneumonia: ARDS or not? Crit Care 24: 154, 2020. https://doi.org/10.1186/s13054-020-02880-Z

GHATI A, DAM P, TASDEMIR D, KATI A, SELLAMI H, SEZGIN GC, ILDIZ N, FRANCO OL, MANDAL AK, OCSOY I: Exogenous pulmonary surfactant: A review focused on adjunctive therapy for severe acute respiratory syndrome coronavirus 2 including SP-A and SP-D as added clinical marker. Curr Opin Colloid Interface Sci 51: 101413, 2021. https://doi.org/10.1016/j.cocis.2020.101413

GILLE C, SPRING B, BERNHARD W, GEBHARD C, BASILE D, LAUBER K, POETS CF, ORLIKOWSKY TW: Differential effect of surfactant and its saturated phosphatidylcholines on human blood macrophages. J Lipid Res 48: 307-317, 2007. https://doi.org/10.1194/jlr.M600451-JLR200

GLASSER SW, WITT TL, SENFT AP, BAATZ JE, FOLGER D, MAXFIELD MD, AKINBI HT, NEWTON DA, PROWS DR, KORFHAGEN TR: Surfactant protein C-deficient mice are susceptible to respiratory syncytial virus infection. Am J Physiol Lung Cell Mol Physiol 297: L64-L72, 2009. https://doi.org/10.1152/ajplung.90640.2008

GOTTS JE, ABBOTT J, MATTHAY MA: Influenza causes prolonged disruption of the alveolar-capillary barrier in mice unresponsive to mesenchymal stem cell therapy. Am J Physiol Lung Cell Mol Physiol 307: L395-L406, 2014. https://doi.org/10.1152/ajplung.00110.2014

HAN S, MALLAMPALLI RK: The role of surfactant in lung disease and host defense against pulmonary infections. Ann Am Thorac Soc 12: 765-774, 2015. https://doi.org/10.1513/AnnalsATS.201411-507FR

HAN Y, DUAN X, YANG L, NILSSON-PAYANT BE, WANG P, DUAN F, TANG X, YARON TM, ZHANG T, UHL S, BRAM Y, RICHARDSON C, ZHU J, ZHAO Z, REDMOND D, HOUGHTON S, NGUYEN DT, XU D, WANG X, JESSURUN J, ET AL.: Identification of SARS-CoV-2 inhibitors using lung and colonic organoids. Nature 589: 270-275, 2021. https://doi.org/10.1038/s41586-020-2901-9

HARTSHORN KL: Role of surfactant protein A and D (SP-A and SP-D) in human antiviral host defense. Front Biosci (Schol Ed) 2: 527-546, 2010. https://doi.org/10.2741/s83

HECHING M, LEV S, SHITENBERG D, DICKER D, KRAMER MR: Surfactant for the treatment of ARDS in a patient with coronavirus disease 2019. Chest 160: E9-E12, 2021. https://doi.org/10.1016/j.chest.2021.01.028

HENNIGHAUSEN L, LEE HK: Activation of the SARS-CoV-2 receptor Ace2 by cytokines through pan JAK-STAT enhancers. BioRxiv (Preprint) 2020: 089045, 2020. https://doi.org/10.1101/2020.05.11.089045 Update in: Cell Rep 32: 108199, 2020.

HERTING E, HÄRTEL C, GÖPEL W: Less invasive surfactant administration: Best practices and unanswered questions. Curr Opin Pediatr 32: 228-234, 2020. https://doi.org/10.1097/MOP.0000000000000878

HIEMSTRA PS, AMATNGALIM GD, VAN DER DOES AM, TAUBE C: Antimicrobial peptides and innate lung defenses: Role in infectious and noninfectious lung diseases and therapeutic applications. Chest 149: 545-551, 2016. https://doi.org/10.1378/chest.15-1353

HSIEH MH, BEIRAG N, MURUGAIAH V, CHOU YC, KUO WS, KAO HF, MADAN T, KISHORE U, WANG JY: Human surfactant protein D binds spike protein and acts as an entry inhibitor of SARS-CoV-2 pseudotyped viral particles. Front Immunol 12: 641360, 2021. https://doi.org/10.3389/fimmu.2021.641360

ISLAM ABMMK, KHAN MA: Lung transcriptome of a COVID-19 patient and systems biology predictions suggest impaired surfactant production which may be druggable by surfactant therapy. Sci Rep 10: 19395, 2020. https://doi.org/10.1038/s41598-020-76404-8

JOHANSSON J, CURSTEDT T: Molecular structures and interactions of pulmonary surfactant components. Eur J Biochem 244: 675-693, 1997. https://doi.org/10.1111/j.1432-1033.1997.00675.x

KANDASAMY P, NUMATA M, BERRY KZ, FICKES R, LESLIE CC, MURPHY RC, VOELKER DR: Structural analogs of pulmonary surfactant phosphatidylglycerol inhibit toll-like receptor 2 and 4 signaling. J Lipid Res 57: 993-1005, 2016. https://doi.org/10.1194/jlr.M065201

KATSURA H, SONTAKE V, TATA A, KOBAYASHI Y, EDWARDS CE, HEATON BE, KONKIMALLA A, ASAKURA T, MIKAMI Y, FRITCH EJ, LEE PJ, HEATON NS, BOUCHER RC, RANDELL SH, BARIC RS, TATA PR: Human lung stem cell-based alveolospheres provide insights into SARS-CoV-2-mediated interferon responses and pneumocyte dysfunction. Cell Stem Cell 27: 890-904.e8. 2020. https://doi.org/10.1016/j.stem.2020.10.005 
KERGET B, KERGET F, KOÇAK AO, KIZILTUNÇ A, ARAZ Ö, UÇAR EY, AKGÜN M: Are serum interleukin 6 and surfactant protein D levels associated with the clinical course of COVID-19? Lung 198: 777-784, 2020. https://doi.org/10.1007/s00408-020-00393-8

KISHORE U, BULLA R, MADAN T: Editorial: Odyssey of surfactant proteins SP-A and SP-D: Innate immune surveillance molecules. Front Immunol 11: 394, 2020. https://doi.org/10.3389/fimmu.2020.00394

KITAOKA H, KOBAYASHI H, TAKIMOTO T, KIJIMA T: Proposal of selective wedge instillation of pulmonary surfactant for COVID-19 pneumonia based on computational fluid dynamics simulation. BMC Pulm Med 21: 62, 2021. https://doi.org/10.1186/s12890-021-01435-4

KOLOMAZNIK M, NOVA Z, CALKOVSKA A: Pulmonary surfactant and bacterial lipopolysaccharide: the interaction and its functional consequences. Physiol Res 66 (Suppl 2): S147-S157, 2017. https://doi.org/10.33549/physiolres.933672

KONOPKA KE, NGUYEN T, JENTZEN JM, RAYES O, SCHMIDT CJ, WILSON AM, FARVER CF, MYERS JL: Diffuse alveolar damage (DAD) resulting from coronavirus disease 2019 infection is morphologically indistinguishable from other causes of DAD. Histopathology 77: 570-578, 2020. https://doi.org/10.1111/his.14180

KOUMBOURLIS AC, MOTOYAMA EK: Lung mechanics in COVID-19 resemble respiratory distress syndrome, not acute respiratory distress syndrome: Could surfactant be a treatment? Am J Respir Crit Care Med 202: 624-626, 2020. https://doi.org/10.1164/rccm.202004-1471LE

KUMAR P: Co-aerosolized pulmonary surfactant and ambroxol for COVID-19 ARDS intervention: What are we waiting for? Front Bioeng Biotechnol 8: 577172, 2020. https://doi.org/10.3389/fbioe.2020.577172

KURONUMA K, MITSUZAWA H, TAKEDA K, NISHITANI C, CHAN ED, KUROKI Y, NAKAMURA M, VOELKER DR: Anionic pulmonary surfactant phospholipids inhibit inflammatory responses from alveolar macrophages and U937 cells by binding the lipopolysaccharide-interacting proteins CD14 and MD-2. J Biol Chem 284: 25488-25500, 2009. https://doi.org/10.1074/jbc.M109.040832

LAMERS MM, VAN DER VAART J, KNOOPS K, RIESEBOSCH S, BREUGEM TI, MYKYTYN AZ, BEUMER J, SCHIPPER D, BEZSTAROSTI K, KOOPMAN CD, GROEN N, RAVELLI RBG, DUIMEL HQ, DEMMERS JAA, VERJANS GMGM, KOOPMANS MPG, MURARO MJ, PETERS PJ, CLEVERS H, HAAGMANS BL: An organoid-derived bronchioalveolar model for SARS-CoV-2 infection of human alveolar type II-like cells. EMBO J 40: e105912, 2021. https://doi.org/10.15252/embj.2020105912

LEIBEL SL, MCVICAR RN, WINQUIST AM, NILES WD, SNYDER EY: Generation of complete multi-cell patientspecific induced pluripotent stem cells for infectious disease modeling and therapeutics validation. Curr Protoc Stem Cell Biol 54: e118, 2020. https://doi.org/10.1002/cpsc.118

LEIBEL SL, SUN X: Halting SARS-CoV-2: lung organoids step up to the plate. EMBO J 40: e107651, 2021. https://doi.org/10.15252/embj.2021107651

LI X, MA X: Acute respiratory failure in COVID-19: is it "typical" ARDS? Crit Care 24: $198,2020$. https://doi.org/10.1186/s13054-020-02911-9

LIU A, ZHANG X, LI R, ZHENG M, YANG S, DAI L, WU A, HU C, HUANG Y, XIE M, CHEN Q: Overexpression of the SARS-CoV-2 receptor ACE2 is induced by cigarette smoke in bronchial and alveolar epithelia. J Pathol 253: 17-30, 2021. https://doi.org/10.1002/path.5555

LOPEZ-RODRIGUEZ E, PEREZ-GIL J: Structure-function relationships in pulmonary surfactant membranes: from biophysics to therapy. Biochim Biophys Acta 1838: 1568-1585, 2014. https://doi.org/10.1016/j.bbamem.2014.01.028

LUKASSEN S, CHUA RL, TREFZER T, KAHN NC, SCHNEIDER MA, MULEY T, WINTER H, MEISTER M, VEITH C, BOOTS AW, HENNIG BP, KREUTER M, CONRAD C, EILS R: SARS-CoV-2 receptor ACE2 and TMPRSS2 are primarily expressed in bronchial transient secretory cells. EMBO J 39: e105114, 2020. https://doi.org/10.15252/embj.20105114

MADAN T, BISWAS B, VARGHESE PM, SUBEDI R, PANDIT H, IDICULA-THOMAS S, KUNDU I, ROOGE S, AGARWAL R, TRIPATHI DM, KAUR S, GUPTA E, GUPTA SK, KISHORE U: A recombinant fragment of human surfactant protein D binds spike protein and inhibits infectivity and replication of SARS-CoV-2 in clinical samples. Am J Respir Cell Mol Biol 65: 41-53, 2021. https://doi.org/10.1165/rcmb.2021-0005OC 
MANDATO C, VAJRO P. Pulmonary lipid modulation: A possible therapeutic target for SARS-CoV-2 infection. Med Hypotheses 149: 110529, 2021. https://doi.org/10.1016/j.mehy.2021.110529

MASON RJ: Biology of alveolar type II cells. Respirology 11 (Suppl 1): S12-S15, 2006. https://doi.org/10.1111/j.14401843.2006.00800.x

MASON RJ: Thoughts on the alveolar phase of COVID-19. Am J Physiol Lung Cell Mol Physiol 319: L115-L120, 2020. https://doi.org/10.1152/ajplung.00126.2020

MIKOLKA P, CURSTEDT T, FEINSTEIN R, LARSSON A, GRENDAR M, RISING A, JOHANSSON J: Impact of synthetic surfactant CHF5633 with SP-B and SP-C analogues on lung function and inflammation in rabbit model of acute respiratory distress syndrome. Physiol Rep 9: e14700, 2021. https://doi.org/10.14814/phy2.14700

MIRASTSCHIJSKI U, DEMBINSKI R, MAEDLER K: Lung surfactant for pulmonary barrier restoration in patients with COVID-19 pneumonia. Front Med (Lausanne) 7: 254, 2020. https://doi.org/10.3389/fmed.2020.00254

MOKRÁ D: Acute lung injury - from pathophysiology to treatment. Physiol Res 69 (Suppl 3): S353-S366, 2020. https://doi.org/10.33549/physiolres.934602

MORRIS G, BORTOLASCI CC, PURI BK, OLIVE L, MARX W, O'NEIL A, ATHAN E, CARVALHO AF, MAES M, WALDER K, BERK M: The pathophysiology of SARS-CoV-2: A suggested model and therapeutic approach. Life Sci 258: 118166, 2020. https://doi.org/10.1016/j.lfs.2020.118166

MULUGETA S, BEERS MF: Surfactant protein C: Its unique properties and emerging immunomodulatory role in the lung. Microbes Infect 8: 2317-2323, 2006. https://doi.org/10.1016/j.micinf.2006.04.009

MYTI D, GUNJAK M, CASADO F, KHAGHANI RAZIABAD S, NARDIELLO C, VADÁSZ I, HEROLD S, PRYHUBER G, SEEGER W, MORTY RE: Elevated FiO2 increases SARS-CoV-2 co-receptor expression in respiratory tract epithelium. Am J Physiol Lung Cell Mol Physiol 319: L670-L674, 2020. https://doi.org/10.1152/japplphysiol.00022.2002

NOVA Z, SKOVIEROVA H, CALKOVSKA A: Alveolar-capillary membrane-related pulmonary cells as a target in endotoxin-induced acute lung injury. Int J Mol Sci 20: 831, 2019. https://doi.org/10.3390/ijms20040831

NOVA Z, SKOVIEROVA H, STRNADEL J, HALASOVA E, CALKOVSKA A: Short-term versus long-term culture of A549 cells for evaluating the effects of lipopolysaccharide on oxidative stress, surfactant proteins and cathelicidin LL-37. Int J Mol Sci 21: 1148, 2020. https://doi.org/10.3390/ijms21031148

NUMATA M, CHU HW, DAKHAMA A, VOELKER DR: Pulmonary surfactant phosphatidylglycerol inhibits respiratory syncytial virus-induced inflammation and infection. Proc Natl Acad Sci U S A 107: 320-325, 2010. https://doi.org/10.1073/pnas.0909361107

NUMATA M, MITCHELL JR, TIPPER JL, BRAND JD, TROMBLEY JE, NAGASHIMA Y, KANDASAMY P, CHU HW, HARROD KS, VOELKER DR: Pulmonary surfactant lipids inhibit infections with the pandemic H1N1 influenza virus in several animal models. J Biol Chem 295: 1704-1715, 2020. https://doi.org/10.1074/jbc.RA119.012053

OCHS M, TIMM S, ELEZKURTAJ S, HORST D, MEINHARDT J, HEPPNER FL, WEBER-CARSTENS S, HOCKE AC, WITZENRATH M: Collapse induration of alveoli is an ultrastructural finding in a COVID-19 patient. Eur Respir J 57: 2004165, 2021. https://doi.org/10.1183/13993003.04165-2020

OPRINCA GC, MUJA LA: Postmortem examination of three SARS-CoV-2-positive autopsies including histopathologic and immunohistochemical analysis. Int J Legal Med 135: 329-339, 2021. https://doi.org/10.1007/s00414-020-02406-w

OTÁHAL M, MLČEK M, VÍTKOVÁ I, KITTNAR O: A novel experimental model of acute respiratory distress syndrome in pig. Physiol Res 65 (Suppl 5): S643-S651, 2016. https://doi.org/10.33549/physiolres.933539

PACES J, STRIZOVA Z, SMRZ D, CERNY J: COVID-19 and the immune system. Physiol Res 69: 379-388, 2020. https://doi.org/10.33549/physiolres.934492

PEDAN H, JANOSOVA V, HAJTMAN A, CALKOVSKY V: Non-reflex defense mechanisms of upper airway mucosa: Possible clinical application. Physiol Res 69 (Suppl 1): S55-S67, 2020. https://doi.org/10.33549/physiolres.934404

PIVA S, DIBLASI RM, SLEE AE, JOBE AH, ROCCARO AM, FILIPPINI M, LATRONICO N, BERTONI M, MARSHALL JC, PORTMAN MA: Surfactant therapy for COVID-19 related ARDS: a retrospective casecontrol pilot study. Respir Res 22: 20, 2021. https://doi.org/10.1186/s12931-020-01603-w 
ROSAS LE, DOOLITTLE LM, JOSEPH LM, EL-MUSA H, NOVOTNY MV, HICKMAN-DAVIS JM, HITE RD, DAVIS IC: Post-exposure liponucleotide prophylaxis and treatment attenuates ARDS in influenza-infected mice. Am J Respir Cell Mol Biol 64: 677-686, 2021. https://doi.org/10.1165/rcmb.2020-0465OC

RUARO B, SALTON F, BRAGA L, WADE B, CONFALONIERI P, VOLPE MC, BARATELLA E, MAIOCCHI S, CONFALONIERI M: The history and mystery of alveolar epithelial type II cells: Focus on their physiologic and pathologic role in lung. Int J Mol Sci 22: 2566, 2021. https://doi.org/10.3390/ijms22052566

SANTANA MF, PINTO RAA, MARCON BH, MEDEIROS LCAS, MORAIS TBDN, DIAS LC, SOUZA LP, MELO GC, MONTEIRO WM, LACERDA MVG, VAL FA, LALWANI PJ, FERREIRA LCL: Pathological findings and morphologic correlation of the lungs of autopsied patients with SARS-CoV-2 infection in the Brazilian Amazon using transmission electron microscopy. Rev Soc Bras Med Trop 54: e0850, 2021. https://doi.org/10.1590/0037-8682-0850-2020

SCHOUSBOE P, WIESE L, HEIRING C, VERDER H, POORISRISAK P, VERDER P, NIELSEN HB: Assessment of pulmonary surfactant in COVID-19 patients. Crit Care 24: 552, 2020. https://doi.org/10.1186/s13054-020-03268-9

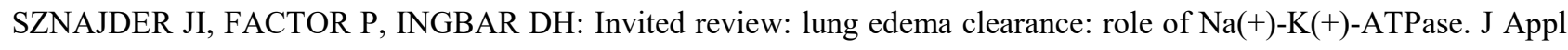
Physiol (1985) 93: 1860-1866, 2002. https://doi.org/10.1152/japplphysiol.00022.2002

TAKANO H: Pulmonary surfactant itself must be a strong defender against SARS-CoV-2. Med Hypotheses 144: 110020, 2020. https://doi.org/10.1016/j.mehy.2020.110020

TEKOS F, SKAPERDA Z, GOUTZOURELAS N, PHELPS DS, FLOROS J, KOURETAS D: The importance of redox status in the frame of lifestyle approaches and the genetics of the lung innate immune molecules, SP-A1 and SP-A2, on differential outcomes of COVID-19 infection. Antioxidants (Basel) 9: 784, 2020. https://doi.org/10.3390/antiox9090784

TREVISAN M, RICCETTI S, SINIGAGLIA A, BARZON L: SARS-CoV-2 infection and disease modelling using stem cell technology and organoids. Int J Mol Sci 22: 2356, 2021. https://doi.org/10.3390/ijms22052356

VAŠKŮ A: Covid-19 infection and the host genetic predisposition: does it exist? Physiol Res 69: 511-514, 2020. https://doi.org/10.33549/physiolres.934504

VELDHUIZEN RAW, ZUO YY, PETERSEN NO, LEWIS JF, POSSMAYER F: The COVID-19 pandemic: a target for surfactant therapy? Expert Rev Respir Med 15: 597-608, 2021. https://doi.org/10.1080/17476348.2021.1865809

VOELKER DR, NUMATA M: Phospholipid regulation of innate immunity and respiratory viral infection. J Biol Chem 294: 4282-4289, 2019. https://doi.org/10.1074/jbc.AW118.003229

WATSON A, MADSEN J, CLARK HW: SP-A and SP-D: Dual functioning immune molecules with antiviral and immunomodulatory properties. Front Immunol 11: 622598, 2021. https://doi.org/10.3389/fimmu.2020.622598

WRIGHT JR: Immunoregulatory functions of surfactant proteins. Nat Rev Immunol 5: 58-68, 2005. https://doi.org/10.1038/nri1528

YAMAGATA T, YAMAGATA Y, NISHIMOTO T, HIRANO T, NAKANISHI M, MINAKATA Y, ICHINOSE M, DAGENAIS A, BERTHIAUME Y: The regulation of amiloride-sensitive epithelial sodium channels by tumor necrosis factor-alpha in injured lungs and alveolar type II cells. Respir Physiol Neurobiol 166: 16-23, 2009. https://doi.org/10.1016/j.resp.2008.12.008

YAO Y, WANG H, LIU Z: Expression of ACE2 in airways: Implication for COVID-19 risk and disease management in patients with chronic inflammatory respiratory diseases. Clin Exp Allergy 50: 1313-1324, 2020. https://doi.org/10.1111/cea.13746

ZIEGLER CGK, ALLON SJ, NYQUIST SK, MBANO IM, MIAO VN, TZOUANAS CN, CAO Y, YOUSIF AS, BALS J, HAUSER BM, FELDMAN J, MUUS C, WADSWORTH MH 2ND, KAZER SW, HUGHES TK, DORAN B, GATTER GJ, VUKOVIC M, TALIAFERRO F, MEAD BE, GUO Z, ET AL.: SARS-CoV-2 Receptor ACE2 is an interferon-stimulated gene in human airway epithelial cells and is detected in specific cell subsets across tissues. Cell 181: 1016-1035.e19, 2020. https://doi.org/10.1016/j.cell.2020.04.035

ZISSEL G, ERNST M, RABE K, PAPADOPOULOS T, MAGNUSSEN H, SCHLAAK M, MULLER-QUERNHEIM J: Human alveolar epithelial cells type II are capable of regulating T-cell activity. J Investig Med 48: 66-75, 2000. 
ZOU X, CHEN K, ZOU J, HAN P, HAO J, HAN Z: Single-cell RNA-seq data analysis on the receptor ACE2 expression reveals the potential risk of different human organs vulnerable to 2019-nCoV infection. Front Med 14: 185-192, 2020. https://doi.org/10.1007/s11684-020-0754-0

https://clinicaltrials.gov/

https://clinicaltrials.gov/ct2/show/NCT04362059

https://clinicaltrials.gov/ct2/show/NCT04375735

https://clinicaltrials.gov/ct2/show/NCT04384731

https://clinicaltrials.gov/ct2/show/NCT04389671

https:/clinicaltrials.gov/ct2/show/NCT04502433

https://clinicaltrials.gov/ct2/show/NCT04568018

https://clinicaltrials.gov/ct2/show/NCT04847375 